\author{
JAN GOLA \\ ORCID: 0000-0001-9236-9259 \\ Uniwersytet Wrocławski \\ jan.gola@uwr.edu.pl
}

\title{
Między gospodarnością a niegospodarnością działań organów administracji gospodarczej
}

\begin{abstract}
Abstrakt: W artykule zaznacza się, że działania podejmowane przez organy administracji gospodarczej powinny charakteryzować się wysokim stopniem gospodarności, który jest gwarancją prawidłowego zarządu mieniem publicznym. Może to wpływać na oszczędność w wydatkowaniu środków finansowych pozostających w gestii szeroko rozumianego sektora publicznego. Powinno się jednocześnie dążyć do wprowadzenia takich zmian w polskim ustawodawstwie, które ograniczą niegospodarność i wpłyną na ekonomiczny rozwój państwa oraz zaufanie obywateli do organów sprawujących władzę publiczną. Podkreślono, że płaszczyzny zarówno gospodarności, jak i niegospodarności w działaniach organów administracji gospodarczej są uwarunkowane prawidłowymi decyzjami ustawodawcy. Jego racjonalne działania legislacyjne mogą doprowadzić do ograniczenia wielu patologii $\mathrm{w}$ administracji publicznej.
\end{abstract}

Słowa kluczowe: gospodarność, niegospodarność, organy administracji publicznej.

\section{Wprowadzenie}

W społecznej gospodarce rynkowej organy administracji gospodarczej wywierają istotny wpływ na funkcjonowanie systemu ekonomicznego państwa. Podejmowane przez nie działania powinny się charakteryzować wysokim stopniem gospodarności, który jest gwarancją prawidłowego zarządu mieniem publicznym. Może to wpływać na oszczędność w wydatkowaniu środków finansowych pozostających w gestii szeroko rozumianego sektora publicznego. Pozytywnie oddziałuje to również na zmniejszenie patologii często występujących w sferze administracji publicznej, takich jak korupcja, nepotyzm czy pranie brudnych pieniędzy. Powinno się dążyć więc de lege ferenda do wprowadzenia takich zmian, które ograniczą niegospodarność i jednocześnie wpłyną na ekonomiczny rozwój pań- 
stwa oraz zaufanie obywateli do organów sprawujących władzę publiczną w Polsce. W artykule zostaną zatem przedstawione dwie wskazane kwestie związane z korzystaniem z mienia publicznego - pozytywna płaszczyzna gospodarności oraz negatywna niegospodarności. Prawidłowa interpretacja tych pojęć może bowiem wpływać na proces wydatkowania pieniędzy publicznych przez organy administracji gospodarczej.

\section{Gospodarność w działaniach organów administracji gospodarczej}

Gospodarność zajmuje istotne miejsce wśród konstytucyjnoprawnych kryteriów prawidłowego zarządu mieniem publicznym ${ }^{1}$. Językoznawcy zaznaczają, że

mianem gospodarnego określamy kogoś, kto umie dobrze i oszczędnie gospodarować tym, co posiada, lub tym, co mu powierzono, kto umiejętnie czymś zarządza, kto umiejętnie prowadzi jakąś działalność, kto - w wypadku zawiadywania pieniędzmi — właściwie je użytkuje, aby osiągnąć wyznaczony cel$^{2}$.

Wskazuje się ponadto, że przez kryterium gospodarności trzeba rozumieć zbiór czynników, na podstawie których oceniamy, czy dobrze i oszczędnie zawiaduje się czymś powierzonym do użytkowania oraz czy umiejętnie prowadzi się jakąś działalność ${ }^{3}$, a także czy właściwie operuje się środkami finansowymi przeznaczonymi do zrealizowania jakiegoś celu ${ }^{4}$. Ocena pod kątem gospodarności stanowi jeden z podstawowych elementów prawnego modelu Najwyższej Izby

1 Warto zauważyć, że pozostałe kryteria to celowość, rzetelności i legalność; zob. A. Chełmoński, Zasady publicznego prawa gospodarczego, [w:] Zasady prawa gospodarczego. Materiaty konferencyjne, red. A. Śmieja, Wrocław 1999, s. 50. Na temat gospodarności w ujęciu nauk ekonomicznych pisał $\mathrm{O}$. Lange. Zdaniem autora gospodarność to pewne formalne ujęcie prawidłowości działania gospodarczego, zgodnie z którym racjonalne gospodarowanie dotyczy optymalnego wykorzystania środków przy jednoczesnym zapobieganiu ich marnotrawieniu; zob. idem, Ekonomia polityczna, t. 1-2, Warszawa 1978, s. 147; por. F. Leszczyński, Zasada gospodarności w pogladach polskich ekonomistów okresu międzywojennego: Taylor - Caro - Biegleisen, „Prace Naukowe Uniwersytetu Ekonomicznego we Wrocławiu" 455, 2016, s. 83-84.

2 J. Miodek, Ekspertyza na temat interpretacji pojęć: kryterium legalności, gospodarności, celowości i rzetelności, zawartych $w$ art. 203 Konstytucji RP $i w$ art. 5 ustawy o Najwyższej Izby Kontroli, [w:] Specjalne posiedzenie Kolegium Najwyższej Izby Kontroli poświęcone kryterium kontroli Najwyższej Izby Kontroli w świetle Konstytucji RP i ustawy o NIK, Warszawa 2002, s. 5-6.

3 Gospodarność można również rozpatrywać w kontekście wyznaczników uniwersalnego pojęcia działalności gospodarczej, które zostało zamieszczone przez ustawodawcę w art. 3 ustawy z dnia 8 marca 2018 — Prawo przedsiębiorców (Dz.U. z 2018 r. poz. 684 z późn. zm.); zob. E. Komierzyńska-Orlińska, Komentarz do art. 3 ustawy - Prawo przedsiębiorców, [w:] Konstytucja biznesu. Komentarz, red. M. Wierzbowski, Warszawa 2019, s. 48 n.

4 J. Miodek, op. cit., s. 6. 
Kontroli. Kryterium to znalazło się już bowiem w ustawie z dnia 3 czerwca 1921 roku o Kontroli Państwowej ${ }^{5}$, a

kontrola działalności gospodarczych i finansowych władz i urzędów państwowych obejmowała wówczas m.in. ocenę, czy wykonane były one z należytą oszczędnością, a przy tym celowo pod względem gospodarczym. Oddaje to zasadniczy sens omawianego kryterium, powiązanego w swej istocie $\mathrm{z}$ badaniem efektywności i skuteczności wykorzystania środków finansowych do realizacji przyjętych uprzednio założeń6.

K. Strzyczkowski zwraca uwagę, że działania administracji orientowane są przez określone, swoiste dla administracji, wzorce racjonalności — jednym z nich jest właśnie gospodarność, będąca jedną z podstaw działań ingerencyjnych administracji w sferę gospodarki, konstytuowanej przez chronione konstytucyjnie wolności oraz prawa podmiotowe ${ }^{7}$. Z kolei K. Kiczka, opierając się na Podręczniku kontrolera Najwyższej Izby Kontroli, podkreśla, że

gospodarność obejmuje badanie oszczędnego i wydajnego wykorzystania środków; uzyskania właściwej relacji nakładów do efektów (czy wynik działalności w warunkach, w jakich działała kontrolowana jednostka, można było osiągnąć mniejszym nakładem środków lub czy zastosowanymi środkami można było osiągnąć lepsze wyniki); wykorzystania możliwości zapobieżenia lub ograniczenia wysokości zaistniałych szkód (strat) w kontrolowanej jednostce. W sytuacji oceny kontrolowanej jednostki jako niegospodarnej należy wskazać ewentualne założenia i metodę rachunku ekonomicznego lub metodę szacunków, stanowiące podstawę (umotywowanie, uzasadnienie) takiej oceny ${ }^{8}$.

Przedstawiciele doktryny prawa konstytucyjnego zauważają natomiast, że gospodarność nie jest kryterium formalnej oceny działalności kontrolowanego podmiotu, a ma jedynie charakter jakościowy, ponieważ badanie określonej sfery funkcjonowania takiego podmiotu obejmuje to, jak wykorzystał on posiadane zasoby, a ocena dotyczy umiejętności działania w pewien pożądany sposób. Zaznacza się,

5 Zgodnie z art. 4 tego przedwojennego aktu prawnego „spełniając swe zdania, Kontrola Państwowa bada, czy czynności gospodarcze i finansowe władz i urzędów państwowych oraz instytucji [...] były legalne, wykonane $\mathrm{z}$ należytą oszczędnością i celowo, pod względem gospodarczym". Norma odwołująca się in concreto do kryterium gospodarności znajduje się też na przykład w art. 6 ustawy. Zgodnie z tym przepisem „Kontrola Państwowa wykonywa kontrolę faktyczną według swego uznania we wszystkich dziedzinach administracji i gospodarki Państwa. Kontrola ta obejmuje: badanie umów i wszelkich zobowiązań, rewizję kas, rachunkowości, rewizje składów, magazynów, inwentarzy i w ogóle majątku państwowego oraz sprawdzanie na miejscu wszelkich robót i dostaw, z punktu widzenia celowości i pod względem gospodarczym" — Dz.U. z 1921 r. poz. 314.

${ }^{6}$ Konstytucja RP, t. 2. Komentarz do art. 87-243, red. M. Safjan, L. Bosek, Warszawa 2016, passim

${ }^{7}$ K. Strzyczkowski, Uwagi o zadaniach nauki o prawnych formach działania, [w:] Instrumenty i formy prawne działania administracji gospodarczej, red. B. Popowska, K. Kokocińska, Poznań 2009, s. 54, cyt. za: K. Kokocińska, Funkcjonalność i dysfunkcjonalność przepisów publicznego prawa gospodarczego z perspektywy kryterium wartości (zagadnienia ogólne), [w:] Dysfunkcje publicznego prawa gospodarczego, red. M. Zdyb, E. Kruk, G. Lubeńczuk, Warszawa 2018, Legalis.

8 K. Kiczka, Z zagadnień ograniczeń antykorupcyjnych w publicznym prawie gospodarczym, [w:] Patologie w administracji publicznej, red. D. Kijowski, P. Suwaj, Warszawa 2009, s. 258.

Prawo 329, 2020

(C) for this edition by CNS 
że model takiego działania zakłada używanie konkretnych środków wyłącznie w takim zakresie, jaki jest konieczny do osiągnięcia celu, oraz że należy sprawdzić, czy kontrolowany podmiot wykorzystał dokładnie tyle zasobów, ile musiał, aby zrealizować konkretne zadania. Przekroczenie wskazanej niezbędnej miary dysponowania środkami pozostawionymi w zarządzie podmiotu jest natomiast przejawem niegospodarności, o której będzie mowa pod koniec rozważań dotyczących przedmiotowego kryterium ${ }^{9}$. Podkreśla się, że gospodarność dotyczy optymalnego dysponowania środkami finansowymi i materialnymi w trakcie prowadzenia działalności ${ }^{10}$. Co ważne, podczas dokonywanych czynności kontrolnych zwraca się uwagę na ekonomiczność działania, która rozumiana jest jako uzyskiwanie jak najlepszych efektów przy najmniejszych nakładach sił i środków ${ }^{11}$.

Organ administracji gospodarczej, wdrażając znamiona przedmiotowego kryterium, powinien stosować się również do zachowania szczególnej staranności przy utrzymaniu prawidłowego zarządu mieniem publicznym zgodnie z przeznaczeniem tego mienia i jego ochroną. Warto mieć na uwadze także to, że kryterium gospodarności ma charakter dyrektywy dotyczącej działań organów kontroli i stanowi swoisty wzorzec determinujący treść oceny co do prawidłowości działań administracji publicznej przy uwzględnieniu omawianego kryterium ${ }^{12}$.

Wskazuje się, że gospodarność — tak jak pozostałe kryteria konstytucyjnoprawne prawidłowego zarządu mieniem publicznym — podlega weryfikacji i ocenie z uwzględnieniem szczególnych regulacji publicznego prawa gospodarczego. Są one rozpatrywane przy uwzględnieniu dwóch elementów,

które stanowią punkt odniesienia przy posługiwaniu się nimi: stopnia ochrony (naruszenia) interesu publicznego (dobra publicznego) w działaniach organu władzy publicznej oraz majątkowych interesów podmiotów zarządu, jeżeli prawo upoważnia do posługiwania się nimi w działaniach zaliczanych do zarządu mieniem publicznym. Zwłaszcza przesłanka naruszenia interesu publicznego pozwala na ustalenie stopnia nieprawidłowości zachowania podmiotu kontrolowanego, co ma znaczenie przy ustalaniu sankcji w przypadku działań ocenianych jako niezgodne z kryteriami kontroli ${ }^{13}$.

Można w tym miejscu wspomnieć na przykład o regulacjach zawartych w ustawie z dnia 16 grudnia 2016 roku o zasadach zarządzania mieniem państwowym ${ }^{14}$. Ustawodawca, uchwalając ten akt prawny, miał na celu reformę sfery wykonywania uprawnień właścicielskich Skarbu Państwa. Zdaniem twórców ustawy państwo

${ }^{9}$ Konstytucja RP, t. 2, passim.

10 Por. B. Sułkowska, Zarządzanie jakością kontroli, „Kontrola Państwowa” 2008, nr 2, s. 48 n.

11 E. Koniuszewska, Środki prawne ograniczajace nadużycia władzy wjednostkach samorzadu terytorialnego, Warszawa 2009.

12 L. Kieres, Kryteria zarzadu mieniem publicznym, [w:] System Prawa Administracyjnego, t. 8a. Publiczne prawo gospodarcze, red. J. Grabowski, L. Kieres, A. Walaszek-Pyzioł, Warszawa 2018, s. 764.

13 Ibidem.

14 Dz.U. z 2016 r. poz. 2259 z późn. zm. 
działające w sferze dominium powinno największy nacisk położyć na efektywne gospodarowanie posiadanym mieniem w celu budowania jego trwałej wartości, a także na jego zabezpieczenie przed ewentualnymi nadużyciami. Ustawodawca we wskazanym akcie prawnym sformułował główne założenia nowego systemu zarządzania mieniem państwowym.

Należy zgodzić się z L. Kieresem, który zauważa, że spory o interpretacje wyników kontroli przeprowadzonej z uwzględnieniem kryterium gospodarności są zjawiskiem towarzyszącym także praktyce wykonywania przez władze publiczne funkcji zarządu mieniem publicznym. Na poparcie tego spostrzeżenia autor wskazał spór między władzami administracji rządowej a jednostkami samorządu terytorialnego o celowość udziału jednostek samorządowych w operacjach giełdowych. Zaznaczył, że

podejmowanie takich czynności może bowiem narzucać obowiązek szczególnej staranności, odnoszony także do funkcji zarządzania mieniem publicznym. Jednak stwierdzenie narzucenia tego obowiązku w związku ze skutkami działań ocenianymi jako straty lub szkody majątkowe może być zarazem obarczone ryzykiem sformułowania zarzutu rozmijania się takich ocen z ekonomicznymi ocenami ich efektywności. Trafność takich ocen może też być rozbieżna, zależnie od czasu ich sporządzenia (bezpośrednio po rozporządzeniu prawami majątkowymi czy też w czasie, który umożliwia sformułowanie oceny krytycznej, uwzględniającej wszystkie konsekwencje ekonomiczne działań w zmieniającej się sytuacji rynkowej) ${ }^{15}$.

Na koniec tej części artykułu trzeba wspomnieć, że gospodarność jest bezpośrednio powiązana $\mathrm{z}$ efektywnością, którą można umiejscowić na granicy płaszczyzn prawa i ekonomii. Wskazuje się na przykład na tak zwaną efektywność gospodarowania, która jest celem prawa konkurencji ${ }^{16}$. Jej osiągnięcie przez organy administracji gospodarczej może być realizacją również pozostałych kryteriów konstytucyjnoprawnych wskazanych wcześniej. Sama zaś efektywność ekonomiczna nie ma jednolitej definicji. P. Nowicki zauważa, że jest ona najczęściej przedstawiana ,jako działanie, którego celem jest osiągnięcie danego efektu przy wykorzystaniu jak najmniejszej ilości dostępnych zasobów lub też osiągnięcie rezultatu przy wykorzystaniu określonej liczby zasobów" ${ }^{17}$. Autor podkreśla ponadto, że pojęcie efektywności ekonomicznej jest powiązane z produktywnością ${ }^{18}$, która dotyczy wytwarzania przez gospodarkę najlepszej kombinacji liczby oraz jakości dóbr i usług przy dostępnych technologiach i rzadkich zasobach ${ }^{19}$.

15 L. Kieres, op. cit., s. 766.

${ }^{16}$ Zob. M. Kępiński, Pojęcie i systematyka prawa konkurencji, [w:] System Prawa Prywatnego, t. 15. Prawo konkurencji, red. M. Kępiński, Warszawa 2013, passim.

17 P. Nowicki, Aksjologia prawa zamówień publicznych. Pomiędzy efektywnościa ekonomiczna a instrumentalizacja, Toruń 2019, s. 275-276.

18 Ibidem, s. 276.

19 P.A. Samuleson, W.D. Nordhaus, Ekonomia, Poznań 2017, s. 4, cyt. za: P. Nowicki, op. cit., s. 277. 


\section{Niegospodarność w działaniach organów administracji gospodarczej}

Przeciwległą płaszczyzną badawczą jest niegospodarność. Organy administracji gospodarczej powinny dążyć w swoich działaniach do jej eliminacji, kierując się jednocześnie ekonomicznymi przesłankami rozwoju państwa. Niegospodarność została spenalizowana przez normodawcę w art. 296 ustawy z dnia 6 czerwca 1997 roku - Kodeks karny ${ }^{20}$. Zgodnie z tym przepisem ten, kto, będąc obowiązany na podstawie przepisu ustawy, decyzji właściwego organu lub umowy do zajmowania się sprawami majątkowymi lub działalnością gospodarczą osoby fizycznej, prawnej albo jednostki organizacyjnej niemającej osobowości prawnej, przez nadużycie udzielonych mu uprawnień lub niedopełnienie ciążącego na nim obowiązku, wyrządza jej znaczną szkodę majątkową, podlega karze pozbawienia wolności od 3 miesięcy do 5 lat $^{21}$.

Przedstawiciele doktryny prawa karnego określają to przestępstwo mianem „karalna niegospodarność”22. Norma ta chroni prawidłowo funkcjonujący obrót gospodarczy w warunkach gospodarki wolnorynkowej. J. Giezek podkreśla, że w piśmiennictwie przyjmuje się także, że ochrona ta rozciąga się na indywidualne interesy majątkowe oraz działalność gospodarczą podmiotów, które uczestniczą w obrocie. Autor zauważa przy tym, że omawiany przepis obejmuje prawnokarną ochroną ponadindywidualne interesy gospodarcze społeczeństwa ${ }^{23}$.

Do przypisania odpowiedzialności karnej ${ }^{24}$ za to przestępstwo konieczne jest oparcie swej negatywnej oceny na obiektywnych i formalnych podstawach ustalonych przez odwołanie się do instytucji nadużycia uprawnień lub niedopełnienia obowiązków ${ }^{25}$. Menadżera nie można więc

20 Dz.U. z 2018 r. poz. 1600 z późn. zm.; dalej: k.k.

21 Zob. A. Charko, Odpowiedzialność karna funkcjonariusza publicznego - wybrane zagadnienia, „Samorząd Terytorialny” 2012, nr 10, s. 48 n.

${ }^{22}$ Zob. R. Zawłocki, Komentarz do art. 296 k.k., [w:] Kodeks karny, część szczególna. Komentarz do art. 222-316, t. 2, red. A. Wąsek, Warszawa 2010, s. 1307.

23 J. Giezek, Komentarz do art. 296 kodeksu karnego, [w:] Kodeks karny. Część szczególna. Komentarz, red. J. Giezek, Warszawa 2014, s. 1154.

24 Przestępstwo określone w art. $296 \S 1$ k.k. jest przestępstwem materialnym. Istotne jest, że świadomością i zamiarem sprawcy objęte jest wyrządzenie szkody majątkowej; zob. wyrok Sądu Apelacyjnego w Warszawie z dnia 11 grudnia 2018 roku, sygn. II AKa 409/18.

25 Sąd Apelacyjny w Warszawie uznał, że szkoda w rozumieniu omawianego przepisu zamyka się uszczerbkiem w majątku danego podmiotu lub utratą spodziewanych korzyści i musi być konkretnie określona w pieniądzu. Zdaniem sądu oznacza to, że jeżeli zachowania podjęte przez osobę określoną w art. $296 \S 1$ k.k. nie są uzasadnione, nie są celowe, nie są etyczne bądź są kontrowersyjne, ale w efekcie ich podjęcia nie została spowodowana szkoda majątkowa w wielkich rozmiarach lub też znaczna szkoda majątkowa, nie ma wówczas podstaw do przypisania sprawcy przestępstwa z art. 296 § 1-3 k.k. — wyrok Sądu Apelacyjnego w Warszawie z dnia 11 grudnia 2018 roku, sygn. II AKa 433/17. 
ukarać za to, iż podjął decyzję nieopłacalną z punku widzenia finansowej polityki danej jednostki. Na próżno bowiem szukać wśród znamion strony przedmiotowej typu czynu zabronionego spenalizowanego w art. $296 \S 1$ k.k. niegospodarności w ścisłym tego słowa znaczeniu, tj. nieumiejętności dobrego zarządzania podmiotem, nieoszczędnego i mechanicznego gospodarowania ${ }^{26}$.

Można również podkreślić, że wskazane nadużycie uprawnień lub niedopełnienie obowiązku to zachowanie wadliwe z punktu widzenia wyboru celów, środków lub sposobów gospodarowania w realizowaniu danego rodzaju działalności gospodarczej i podjęcie nadmiernego ryzyka gospodarczego, a nadmiernie ryzykować może tylko ten uczestnik obrotu gospodarczego, który prowadzi legalną działalność gospodarczą ${ }^{27}$.

W literaturze akcentuje się, że dyskusyjne jest to, czy niegospodarność jest zjawiskiem patologicznym, a jeżeli tak, to czy takim, aby została objęta kryminalizacją. R. Zawłocki wskazuje na szczególny rodzaj niegospodarności — związany z prowadzeniem cudzych spraw gospodarczych w sposób szkodzący właścicielowi przedsiębiorstwa. Badacz zaznacza przy tym, że

przepisy karne w omawianym zakresie pełnią funkcję instrumentów chroniących obrót gospodarczy, a w szczególności - interes uczestników tegoż obrotu (właścicieli przedsiębiorstw) przed szkodliwą niegospodarnością menedżerów prowadzących cudze sprawy gospodarcze. Karalna niegospodarność odnosi się więc zasadniczo do kryminalizacji wąskiego zakresu nieodpowiedniego gospodarowania. Nie zmienia to jednak faktu, że kryminalizacja ta obejmuje aktywność ekonomiczną, co - samo w sobie - stanowi zagrożenie dla podstawowej zasady wolności gospodarczej. $\mathrm{Z}$ tego względu zasada ultima ratio prawa karnego w omawianym przypadku powinna prowadzić do szczególnie restrykcyjnie ujmowanej konieczności ścisłej (zawężającej) interpretacji przepisów karnych określających przestępstwa niegospodarności ${ }^{28}$.

Można zaznaczyć, że przestępstwo niegospodarności należy do przestępstw indywidualnych właściwych, w wypadku których możliwość popełnienia jest uwarunkowana posiadaniem określonych (konkretnych) cech przez jego sprawcę, podczas gdy podmiotem tego przestępstwa może być tylko osoba zajmująca się cudzymi sprawami majątkowymi lub cudzą działalnością gospodarczą ${ }^{29}$. Dotyczy to wszystkich prowadzonych cudzych spraw majątkowych, a karalność nie ogranicza się tylko do majątkowych spraw przedsiębiorcy, czyli sfery aktywności gospodarczej. Obejmuje także wszelkie inne interesy majątkowe innego podmiotu, niezwiązane z prowadzeniem przez niego aktywności gospodarczej ${ }^{30}$. Trzeba ponadto pamiętać, że omawiane przestępstwo, mimo wielości podjętych przez

26 M. Ligęza-Turlakiewicz, G. Turlakiewicz, Granice kreatywnego zachowania menadżerów w kontekście art. 296 § la kodeksu karnego, „Prokuratura i Prawo” 2016, nr 5, s. 48.

27 Wyrok Sądu Najwyższego z dnia 16 lutego 2017 roku, sygn. III KK 238/16.

28 R. Zawłocki, Przestępstwo niegospodarności, [w:] System Prawa Karnego, t. 9. Przestępstwa przeciwko mieniu i gospodarcze, red. R. Zawłocki, Warszawa 2015, s. 453.

29 Por. M. Kopacz, Przestępstwo nadużycia zaufania jako przestępstwo gospodarcze, „Studia Prawnicze i Administracyjne" 2013, nr 1, s. 107 n.

30 T. Oczkowski, Przestęstwa niegospodarności, [w:] System Prawa Handlowego, t. 10. Prawo karne gospodarcze, red. R. Zawłocki, Warszawa 2018, Legalis. 
sprawcę działań (zaniechań), jest niepodzielne, w związku z czym niedopuszczalne jest skazanie sprawcy za fragment takiego przestępstwa, obejmujący kilka czynów i jednoczesne uniewinnienie (umorzenie) w części obejmującej pozostałe czyny (zachowania sprawcze) wchodzące w jego skład ${ }^{31}$.

\section{Zakończenie}

Nie ulega wątpliwości, że kryterium gospodarności w sposób bezpośredni wpływa na oszczędność w wydatkowaniu środków finansowych pozostających w gestii szeroko rozumianego sektora publicznego oraz na stworzenie podstaw korzystania z udziałów gospodarczych przez przedsiębiorców na rynku publicznym. De lege ferenda ustawodawca powinien stworzyć takie środki nadzoru publicznego, które bez przeszkód będą mogły zastosować w praktyce organy do tego upoważnione. Przyczyniać się one powinny de facto do rozwoju gospodarczego kraju. Trzeba jednak pamiętać, że gospodarność środków finansowych pozostających w dyspozycji danego organu administracji gospodarczej musi być koherentnie związana z zasadą efektywności, która również dotyczy prawidłowego gospodarowania mieniem publicznym ${ }^{32}$. To organy administracji gospodarczej odgrywają obecnie ważną rolę w procesie wydatkowania środków publicznych, a ich działania powinny być nacechowane gospodarnością. Można podkreślić, że właśnie te organy muszą stanowić swoisty wzór dla innych organów administracji publicznej oraz przedsiębiorców.

Precyzyjne wyznaczenie zakresu znaczeniowego gospodarności i niegospodarności nie jest jednak łatwe ${ }^{33}$. Terminy te trzeba bowiem stosować, odwołując się do znaczenia językowego oraz jednocześnie uwzględniając kategorię podmiotów kontrolowanych oraz rodzaj działalności poddawanej ocenie w danym wypadku, gdyż tylko tak można stwierdzić, czy dany podmiot działał w sposób umiejętny oraz czy odpowiednio wykorzystał posiadane środki ${ }^{34}$.

Biorąc pod uwagę powyższe, można dokonać konstatacji, że płaszczyzny zarówno gospodarności, jak i niegospodarności w działaniach organów administracji gospodarczej są uwarunkowane prawidłowymi decyzjami ustawodawcy, którego racjonalne działania legislacyjne mogą doprowadzić do ograniczenia wielu patologii życia społecznego. Natomiast organy administracji gospodarczej zawsze powinny dążyć do najbardziej efektywnych metod działania, które będą

31 Wyrok Sądu Najwyższego z dnia 23 maja 2016 roku, sygn. V KK 414/15.

32 Por. P. Kucharski, Kontrola NBP przez Najwyższa Izbę Kontroli w świetle prawa UE, „Europejski Przegląd Sądowy” 2011, nr 2, s. 27.

33 Zob. wyrok Sądu Apelacyjnego w Warszawie z dnia 10 września 2015 roku, sygn. AKa $137 / 15$.

34 Konstytucja RP, t. 2, passim. 
wpływać na osiągnięcie przez nie maksymalnego stopnia tytułowej gospodarności w wydatkowaniu środków publicznych.

\section{Bibliografia}

Charko A., Odpowiedzialność karna funkcjonariusza publicznego - wybrane zagadnienia, „Samorząd Terytorialny" 2012, nr 10.

Chełmoński A., Zasady publicznego prawa gospodarczego, [w:] Zasady prawa gospodarczego. Materiaty konferencyjne, red. A. Śmieja, Wrocław 1999.

Giezek J., Komentarz do art. 296 kodeksu karnego, [w:] Kodeks karny. Część szczególna. Komentarz, red. J. Giezek, Warszawa 2014.

Kępiński M., Pojęcie i systematyka prawa konkurencji, [w:] System Prawa Prywatnego, t. 15. Prawo konkurencji, red. M. Kępiński, Warszawa 2013.

Kiczka K., Z zagadnień ograniczeń antykorupcyjnych w publicznym prawie gospodarczym, [w:] Patologie w administracji publicznej, red. D. Kijowski, P. Suwaj, Warszawa 2009.

Kieres L., Kryteria zarzadu mieniem publicznym, [w:] System Prawa Administracyjnego, t. 8a. Publiczne prawo gospodarcze, red. J. Grabowski, L. Kieres, A. Walaszek-Pyzioł, Warszawa 2018.

Kokocińska K., Funkcjonalność i dysfunkcjonalność przepisów publicznego prawa gospodarczego z perspektywy kryterium wartości (zagadnienia ogólne), [w:] Dysfunkcje publicznego prawa gospodarczego, red. M. Zdyb, E. Kruk, G. Lubeńczuk, Warszawa 2018.

Komierzyńska-Orlińska E., Komentarz do art. 3 ustawy - Prawo przedsiębiorców, [w:] Konstytucja biznesu. Komentarz, red. M. Wierzbowski, Warszawa 2019.

Koniuszewska E., Środki prawne ograniczające nadużycia władzy w jednostkach samorządu terytorialnego, Warszawa 2009.

Konstytucja RP, t. 2. Komentarz do art. 87-243, red. M. Safjan, L. Bosek, Warszawa 2016.

Kopacz M., Przestępstwo nadużycia zaufania jako przestęstwo gospodarcze, „Studia Prawnicze i Administracyjne" 2013, $\mathrm{nr} 1$.

Kucharski P., Kontrola NBP przez Najwyższą Izbę Kontroli w świetle prawa UE, „Europejski Przegląd Sądowy" 2011, nr 2.

Lange O., Ekonomia polityczna, t. 1-2, Warszawa 1978.

Leszczyński F., Zasada gospodarności w poglądach polskich ekonomistów okresu międzywojennego: Taylor - Caro - Biegleisen, „Prace Naukowe Uniwersytetu Ekonomicznego we Wrocławiu" 455, 2016.

Ligęza-Turlakiewicz M., Turlakiewicz G., Granice kreatywnego zachowania menadżerów w kontekście art. 296 \& la kodeksu karnego, „Prokuratura i Prawo” 2016, nr 5.

Miodek J., Ekspertyza na temat interpretacji pojęć: kryterium legalności, gospodarności, celowości i rzetelności, zawartych $w$ art. 203 Konstytucji RP $i$ w art. 5 ustawy o Najwyższej Izby Kontroli, [w:] Specjalne posiedzenie Kolegium Najwyższej Izby Kontroli poświęcone kryterium kontroli Najwyższej Izby Kontroli w świetle Konstytucji RP i ustawy o NIK, Warszawa 2002.

Nowicki P., Aksjologia prawa zamówień publicznych. Pomiędzy efektywnościa ekonomiczna a instrumentalizacja, Torun 2019.

Oczkowski T., Przestęstwa niegospodarności, [w:] System Prawa Handlowego, t. 10. Prawo karne gospodarcze, red. R. Zawłocki, Warszawa 2018.

Samuleson P.A., Nordhaus W.D., Ekonomia, Poznań 2017.

Strzyczkowski K., Uwagi o zadaniach nauki o prawnych formach dziatania, [w:] Instrumenty i formy prawne działania administracji gospodarczej, red. B. Popowska, K. Kokocińska, Poznań 2009. 
Sułkowska B., Zarządzanie jakością kontroli, „Kontrola Państwowa” 2008, nr 2.

Zawłocki R., Komentarz do art. 296 k.k., [w:] Kodeks karny, część szczególna. Komentarz do art. 222-316, t. 2, red. A. Wąsek, Warszawa 2010.

Zawłocki R., Przestęsstwo niegospodarności, [w:] System Prawa Karnego, t. 9. Przestęsstwa przeciwko mieniu i gospodarcze, red. R. Zawłocki, Warszawa 2015.

\title{
Between thriftiness and thriftlessness of activities of public economic administration bodies
}

\begin{abstract}
Summary
The article emphasizes that the activities undertaken by economic administration bodies should be characterized by a high degree of thriftiness, which is a guarantee of proper management of public property. This may affect savings in spending funds remaining under the responsibility of the broadly understood public sector. At the same time, one should strive to introduce such changes in Polish legislation that will limit thriftlessness and affect the economic development of the state and citizens' trust in bodies exercising public authority. It was emphasized that both the level of thriftiness and the level of thriftlessness in the activities of economic administration bodies are dependent on the correct decisions of the legislator. Its rational legislative activities may lead to the reduction of many pathologies in public administration.
\end{abstract}

Keywords: thriftiness, thriftlessness, public administration bodies. 